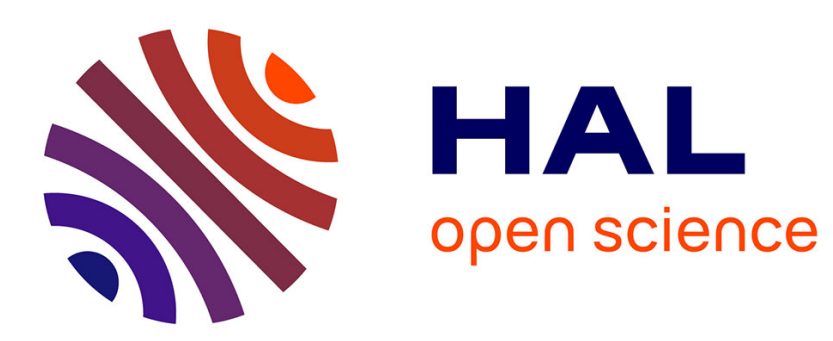

\title{
A cell-intrinsic timer that operates during oligodendrocyte development
}

Beatrice Claude Durand, Martin Raff

\section{To cite this version:}

Beatrice Claude Durand, Martin Raff. A cell-intrinsic timer that operates during oligodendrocyte development. BioEssays, 2000, 22 (1), pp.64-71. 10.1002/(SICI)1521-1878 . hal-02561082

\section{HAL Id: hal-02561082 \\ https://hal.science/hal-02561082}

Submitted on 24 Nov 2020

HAL is a multi-disciplinary open access archive for the deposit and dissemination of scientific research documents, whether they are published or not. The documents may come from teaching and research institutions in France or abroad, or from public or private research centers.
L'archive ouverte pluridisciplinaire HAL, est destinée au dépôt et à la diffusion de documents scientifiques de niveau recherche, publiés ou non, émanant des établissements d'enseignement et de recherche français ou étrangers, des laboratoires publics ou privés. 


\title{
A cell-intrinsic timer that operates during oligodendrocyte development
}

\author{
Béatrice Durand ${ }^{1 *}$ and Martin Raff ${ }^{2}$
}

\begin{abstract}
Summary
Multicellular organisms develop on a predictable schedule that depends on both cell-intrinsic timers and sequential cell-cell interactions mediated by extracellular signals. The interplay between intracellular timers and extracellular signals is well illustrated by the development of oligodendrocytes, the cells that make the myelin in the vertebrate central nervous system. An intrinsic timing mechanism operates in each oligodendrocyte precursor cell to limit the length of time the cell divides before terminally differentiating. This mechanism consists of two components, a timing component, which depends on the mitogen platelet-derived growth factor (PDGF) and measures elapsed time, and an effector component, which depends on thyroid hormone and stops cell division and initiates differentiation at the appropriate time. The cell-cycle inhibitor P27/Kip1 accumulates in the precursor cells as they proliferate and is part of both components of the timer. It seems likely that similar timing mechanisms operate in other cell lineages. BioEssays 22:64-71, 2000.

๑) 2000 John Wiley \& Sons, Inc.
\end{abstract}

Philosophers and physicists have long debated whether time is linear or circular, directional or nondirectional, reversible or irreversible.(1) For biologists, time is unequivocally linear, directional, and irreversible: species evolve, and individual organisms develop on a predictable schedule and invariably senesce and die; there is no going back. An important challenge is to understand the mechanisms that underlie these directional processes.

Besides these linear processes, both individual cells and multicellular systems display various types of cycles, or rhythms, which could, in principle, be involved in timing the progress of development and senescence. Circadian clocks are an example. They control a variety of physiological and behavioural functions in most organisms. (2) It seems unlikely, however, that circadian clocks are used as timing devices in development or senescence, at least in animals, as muta-

${ }^{1}$ Department of Biochemistry, Baylor College of Medicine, Houston, Texas.

${ }^{2}$ Medical Research Council Laboratory for Molecular Cell Biology, University College London, London, United Kingdom.

${ }^{*}$ Correspondence to: Béatrice Durand, Dept of Biochemistry, Baylor College of Medicine, One Baylor Plaza, Houston, TX 77030. E-mail: bdurand@bcm.tmc.edu tions that disable them in flies or mice have little effect on either of these processes. Cells and organisms have clearly developed other ways of keeping time.

Timing in animal development, however, does seem to depend on intracellular timers (reviewed in Refs. 3 and 4), as well as on sequential cell-cell interactions. In principle, an intracellular timer could operate in a number of ways. It could involve noncircadian intracellular oscillators, such as those that control the cell division cycle,(5) or those that generate periodic ion fluxes, (6) or repeating bursts of specific gene expression.(7) Such oscillations seem to be used, like the ticks of a clock, to time some developmental processes, but how this is achieved is unknown. An intracellular timer could work through the sequential activation of a series of genes encoding gene regulatory proteins, with each transcriptional activator activating the next in the sequence, until a final gene product triggers a developmental event. Alternatively, a timer could operate like an hourglass, where the progressive accumulation or loss of a molecule involved in a rate-limiting process serves as a measure of time, with the molecule triggering a developmental event when a threshold level is reached.

\section{Some examples of intracellular developmental timing mechanisms}

An example of an intracellular developmental timing mechanism that makes use of the cell division cycle is seen in the early Xenopus embryo, where zygotic gene transcription begins at a specific time point called the midblastula transition (MBT). The timing of MBT depends on repeated cycles of DNA replication and cell division. Because the cells divide without cell growth, the ratio of nuclear DNA to cytoplasm in each cell increases with each division cycle, until it reaches a critical value that triggers zygotic gene transcription. $(8,9)$ Another example where timing depends on a form of celldivision counting is in the replicative senescence of cultured human fibroblasts, which stop dividing after a limited number of divisions when stimulated by mitogens. In this case, telomeres shorten with each cell division, until they become sufficiently short that they activate a checkpoint mechanism that arrests the cell cycle.(10) Most of the mechanisms that control the timing of development, however, do not seem to depend on cell-division counting. Cells in a developing embryo, for example, frequently differentiate on close to a normal schedule even when cell division has been blocked 


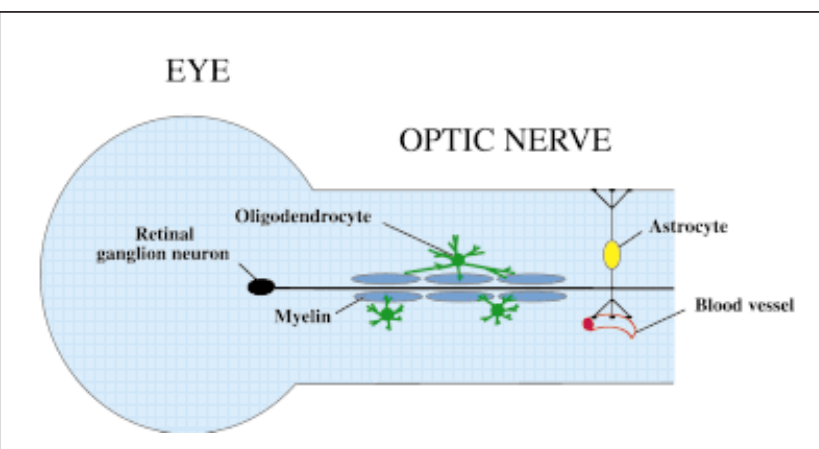

Figure 1. Schematic drawing of the rat optic nerve. The nerve contains the axons of retinal ganglion neurons and two main types of glial cells, astrocytes, which send processes to the surface of the nerve and to blood vessels, and oligodendrocytes, which myelinate the axons.

by drug treatment.(11,12) Moreover, many changes that occur in developing cells over time often occur after the cells have permanently withdrawn from the cell cycle.

Some developmental timers depend on other intracellular cycles. A dramatic example is seen during the development of vertebrate somites, which form every 30 min in early chick embryos. Remarkably, the expression of specific genes in the mesoderm cells that will form the somites in these embryos oscillates with a 30 min periodicity, suggesting that these oscillations somehow determine when these cells assemble into somites. ${ }^{(3,7,13)}$ It remains to be determined how the oscillations are controlled and how they are translated into developmental time.

Some developmental timers do not appear to depend on gene transcription or protein synthesis at all. In Xenopus embryo development, for example, a number of precisely timed early events occur normally even when DNA, RNA, and protein synthesis are inhibited by drug treatment. $(11,14)$ These timers presumably depend on post-translational controls, but their nature remains a mystery.

As mentioned earlier, the timing of development in multicellular organisms depends on more than intracellular timing mechanisms described above. It also depends on cellcell interactions, which are mainly mediated by extracellular signalling molecules. This interplay between intracellular timers and extracellular signals is well illustrated in the development of oligodendrocytes, which are the cells that make myelin in the vertebrate central nervous system and are the main focus of this review.

\section{Timing of glial cell development in cultures of embryonic brain cells}

The vertebrate brain contains a variety of types of glial cells, each of which develops on a predictable schedule. Remarkably, if cells are dissociated from an embryonic rat brain and grown in culture, the major classes of glial cells develop on the same schedule as they do in the developing brain.(15) These findings suggest that the mechanisms that control the timing of glial cell development in vivo also operate in a culture dish, where they are accessible to analysis. The complexity of the brain cell cultures, however, makes such an analysis difficult, which is why we turned to the optic nerve, which contains no neurons and is therefore far simpler.

\section{Glial cell development in the rat optic nerve}

The optic nerve contains the axons of retinal ganglion neurons and two types of glial cells: astrocytes, which support
Figure 2. The roles of extracellular signals in oligodendrocyte precursor cell development in culture. In the absence of the mitogen, PDGF, precursor cells rapidly stop dividing and differentiate, whether or not thyroid hormone $(\mathrm{TH})$ is present. In the presence of PDGF and TH precursor cells isolated from a P7 rat optic nerve divide a maximum of eight times before they stop and differentiate. In the presence of PDGF and the absence of $\mathrm{TH}$ most of the precursor cells keep on dividing and do not differentiate.
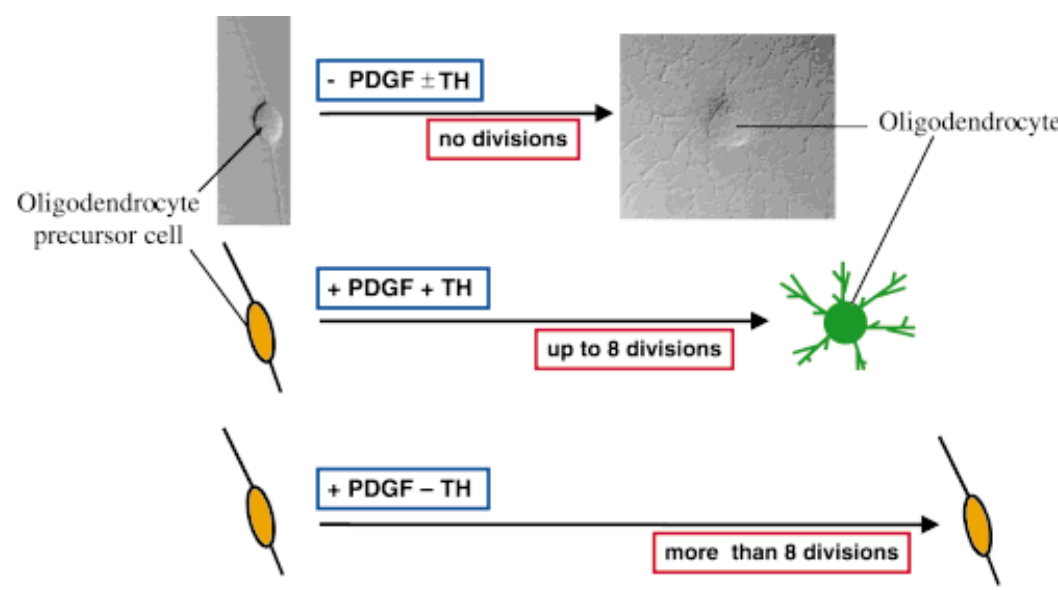

\}

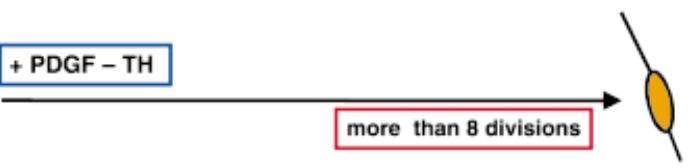

Time 


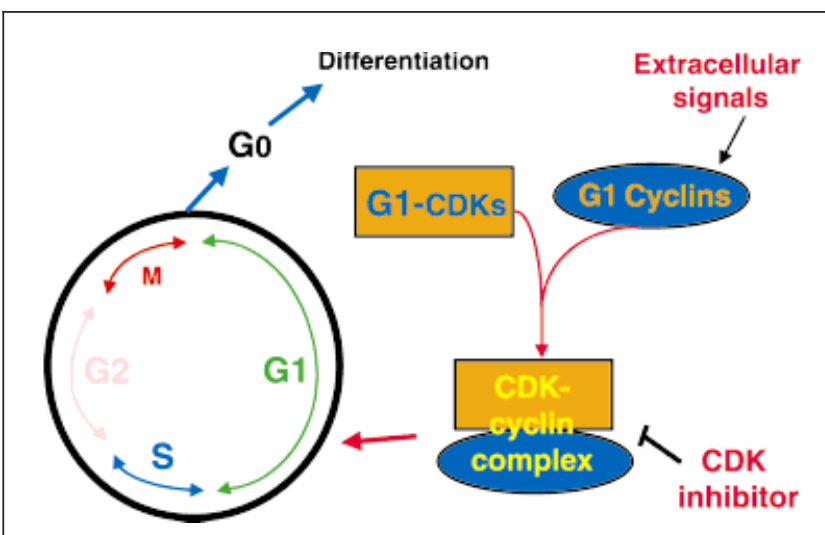

Figure 3. A simplified drawing of the controls on the $\mathrm{G}_{1}-\mathrm{S}$ transition in the cell cycle. The $G_{1}$ cyclin-dependent protein kinases (Cdks) are activated by $\mathrm{G}_{1}$ cyclins and inhibited by Cdk inhibitors, including p27. The synthesis of some of the $\mathrm{G}_{1}$ cyclins is stimulated by extracellular mitogens; in the absence of mitogens, the cells withdraw from the cell cycle and enter a quiescent state $\left(G_{0}\right)$, from where they can differentiate. $M=$ mitosis and cytokinesis.

the axons in the nerve structurally and functionally, and oligodendrocytes, which extend processes that wrap around the axons to form an insulating myelin sheath (Fig. 1). The astrocytes develop from the neuroepithelial cells of the optic stalk, the primordium of the nerve, while the oligodendrocytes develop from precursor cells that migrate into the developing nerve from the brain beginning just before birth. (16) The oligodendrocyte precursor cells divide a limited number of times before they stop and terminally differentiate into postmitotic oligodendrocytes. The first oligodendrocytes appear in the nerve around the day of birth, and their numbers then progressively increase over the next 6 weeks. ${ }^{(17,18)}$

The astrocytes play an important part in oligodendrocyte development. For example, they secrete platelet-derived growth factor (PDGF), the main mitogen that drives proliferation of oligodendrocyte precursor cells. ${ }^{(19,20)}$ In the absence of PDGF, the precursors divide very little in culture, and few oligodendrocytes develop in vivo. ${ }^{(21-23)}$

\section{Oligodendrocyte development in cultures of optic nerve cells}

The normal timing of oligodendrocyte development can be reconstituted in cultures of dissociated embryonic optic nerves, ${ }^{(24)}$ as long as the oligodendrocytes are stimulated to divide by PDGF.(25) The reason the precursors stop dividing and differentiate in such cultures is not because PDGF becomes limiting or because the PDGF receptors on these cells disappear or are no longer activated by PDGF. Adding excess PDGF does not alter the timing of oligodendrocyte

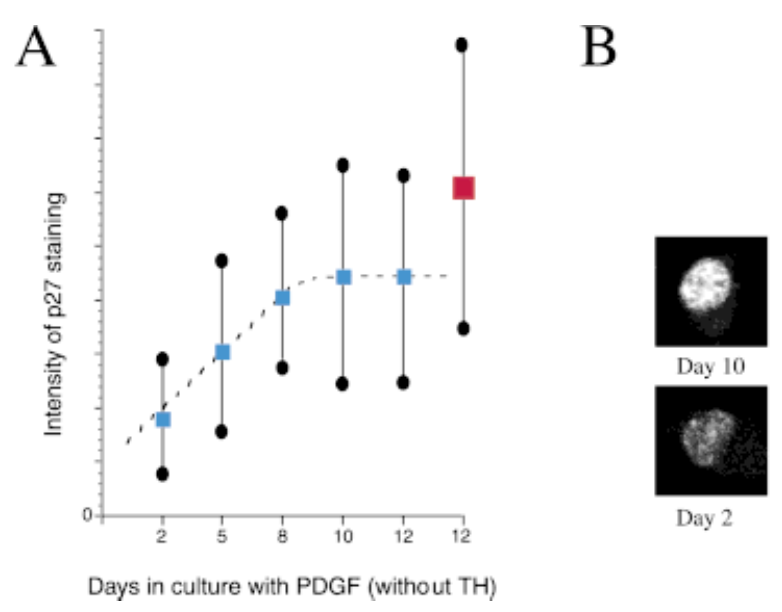

Figure 4. Time course of p27 accumulation in purified oligodendrocyte precursor cells stimulated to divide in culture by PDGF in the absence of TH. (A) The average intensity of p27 immunofluorescence staining in the nucleus $(\square)$ in blue, assessed by quantitative confocal fluorescence microscopy, as well as the lowest and highest values $(\bullet)$ in the cell population, are plotted against days in culture. The intensity of staining in oligodendrocytes, which developed following PDGF removal for 2 days after the 10-day culture period with PDGF, is also shown ( $\square$ ) in red. (B) Confocal fluorescence micrograph of p27 staining in the nucleus of precursor cells after 2 and 10 days in culture.

differentiation,(25) and newly formed oligodendrocytes still express large numbers of PDGF receptors, (26) stimulation of which induces both an increase in cytosolic $\mathrm{Ca}^{2+}(27)$ and immediate-early gene expression. (28) These findings raised the possibility that the precursor cells have a cell-intrinsic mechanism that limits their proliferative capacity and controls when they withdraw from the cell cycle and undergo terminal differentiation.

\section{A cell-intrinsic timer in the oligodendrocyte precursor cell}

When individual or purified oligodendrocyte precursor cells isolated from postnatal day $7(\mathrm{P} 7)$ rat optic nerve are stimulated to proliferate in culture by either astrocytes or saturating amounts of PDGF, the cells divide up to eight times before they stop and differentiate. $(29,30)$ The progeny of an individual precursor cell stop dividing and differentiate at about the same time. ${ }^{29,30)}$ If the two daughter cells of an individual precursor are separated and cultured on astrocyte monolayers in separate microwells, they divide the same number of times before they differentiate, indicating that an intrinsic mechanism operates in the precursor cells to limit the number of times, or the period of time, that the cell normally divides. ${ }^{(29)}$ 
Does the counting mechanism count cell divisions, or does it measure time in some other way? Oligodendrocyte precursor cells cultured at $33^{\circ} \mathrm{C}$ divide more slowly, but stop dividing and differentiate after fewer divisions compared to cells cultured at $37^{\circ} \mathrm{C}$. This suggests that the intrinsic mechanism does not operate by counting cell divisions but, instead, measures elapsed time in some other way.(31) We therefore refer to it as a timer.

\section{Two functional components of the timer}

Although the timer is intrinsic to the precursor cell, its activity depends on extracellular PDGF, which is normally produced by other cells, such as astrocytes in the optic nerve. If a single precursor cell is cultured on its own in the absence of PDGF, it stops dividing and differentiates within 1-2 days. ${ }^{(32)}$ Similarly, in the absence of PDGF, purified precursor cells differentiate prematurely, no matter how high the density of the cells in the culture dish. ${ }^{(18)}$ Thus, the timer only works if the cells are continuously stimulated to proliferate by PDGF.

In addition to PDGF, the timer also needs hydrophobic signals, such as thyroid hormone (TH) or retinoic acid (RA), to function normally. Precursor cells cultured in the presence of mitogens but in the absence of TH or RA keep dividing and do not differentiate(30) (Fig. 2). If TH is added to such a culture after 8 days, when most precursor cells would have differentiated had TH been present, the precursor cells soon stop dividing and differentiate. ${ }^{(30)}$ Thus, in the presence of mitogens and the absence of hydrophobic signals, the cells can still keep track of time, but they seem unable to stop dividing and differentiate when the appropriate time is reached.

Therefore, the timer consists of at least two functional components: (1) a timing component, which depends on PDGF but not TH and measures elapsed time, and (2) an effector component, which is regulated by $\mathrm{TH}$ and stops cell division and initiates differentiation when the timing component indicates it is time. ${ }^{(33)} \mathrm{A}$ similar conclusion was reached by Bögler and Noble,(34) who used a combination of PDGF and fibroblast growth factor (FGF) to keep the precursor cells dividing beyond their normal limit.

All of the studies investigating the intrinsic timing mechanism of oligodendrocyte precursor cells have used cells in culture. Does this timer also operate in the developing nervous system to determine when cells stop dividing and differentiate? Two lines of evidence suggest that it does. First, exposing the P8 rat optic nerve to excess PDGF does not increase the proliferation of oligodendrocyte precursor cells in the nerve. ${ }^{(18)}$ This suggests that precursor cells do not normally stop dividing and start to differentiate because of PDGF deprivation, at least at this stage of development. Second, a cell lineage study in the developing rat brain found that clones of oligodendrocyte lineage cells contained either precursors or oligodendrocytes, but not both,(35) which suggests that the progeny of an individual precursor cell differentiate synchronously.

\section{The role of $\mathbf{p 2 7 / k i p 1}$}

It is not certain whether the timer in oligodendrocyte precursor cells primarily controls the onset of differentiation, the cessation of proliferation, or both. Because the precursor cells stop dividing immediately and differentiate when deprived of PDGF, 25,29$)$ we suspect that the timer primarily controls cell proliferation. If this is the case, the timer must, at some point, interact with the cell-cycle control system that regulates progress through the cell division cycle. Since the cells stop dividing and differentiate in the $G_{1}$ phase of the cell cycle, it is likely that the relevant interactions occur within the control system that operates in $\mathrm{G}_{1}$ (Fig. 3).

The eucaryotic cell cycle is controlled by a family of cyclin-dependent protein kinases (Cdks), which are cyclically activated to trigger the different phases of the cell cycle at the right time and in the right sequence. $(36,37)$ These Cdks are regulated by at least three types of proteins: cyclins activate and direct them to their substrates; kinases and phosphatases activate or inhibit their activity; and cyclindependent kinase inhibitors block the assembly or activity of the cyclin-Cdk complexes. ${ }^{(36-38)}$ Two families of Cdk inhibitors have been identified in mammalian cells, the Cip/Kip family, which includes p21Cip1, p27Kip1, and p57Ink4b, and the Ink4 family, which includes p16 ink4a, p15ink4b, p18ink4c, and p19Ink4d.(39) When over-expressed in cells, each of these inhibitors arrest the cell cycle in $G_{1}$ (Fig. 3). Moreover, some cdk inhibitors are up-regulated when developing cells stop dividing and differentiate, so that they could well play a part in arresting the cell cycle at the appropriate time. ${ }^{(40)}$

In principle, the timer in oligodendrocyte precursor cells might depend on a decrease in a positive intracellular regulator such as a cyclin or Cdk that promotes cell-cycle progression, an increase in a negative intracellular regulator such as a Cdk inhibitor that blocks cell-cycle progression, or both types of mechanism. It would be advantageous to use both mechanisms, as this would make the timer more accurate, and, if one mechanism were defective, the timer would still work, although inaccurately.

Several lines of evidence suggest that the Cdk inhibitor p27/Kip1 (p27) is part of the timer. First, p27 levels are high in oligodendrocytes, both in vivo and in vitro, whereas they are variable in precursor cells.(41) Second, p27 levels increase rapidly when precursor cells in culture are deprived of PDGF; the rate of increase is similar to the rate at which the precursor cells commit to cell-cycle withdrawal and differentiation, suggesting that p27 is part of the effector mechanism. ${ }^{(41)}$ Third, p27 levels progressively increase when P7 precursor cells are cultured in the presence of PDGF but in the absence of $\mathrm{TH},{ }^{(41)}$ conditions where the 
timing component continues to operate, but the effector component is defective. ${ }^{\left({ }^{30}\right)}$ p27 levels plateau after about 8 days in these cultures, when most of the cells would have differentiated had TH been present (Fig. 4). In the absence of $\mathrm{TH}$, however, despite high levels of $\mathrm{p} 27$, cells continue to divide, indicating that high levels of p27 alone are insufficient to stop the cell cycle. Fourth, p27 levels rise faster at $33^{\circ} \mathrm{C}$ than at $37^{\circ} \mathrm{C}$, as would be expected if p27 is part of the timer, since the timer runs faster at the lower temperature. ${ }^{(31)}$ Fifth, and most importantly, oligodendrocyte precursor cells isolated form p27-deficient mice divide with a normal cellcycle time, but many of them go through one or two more divisions compared to wild-type cells before they differentiate.(42) Detailed analysis of p27-deficient cells suggests that they are defective in both the timing ${ }^{(42)}$ and the TH-dependent effector $(42,43)$ components of the timer.

\section{The generality of the p27-dependent timing mechanism}

It seems likely that p27 plays a similar role in limiting cell proliferation and timing the onset of differentiation during normal development in many cell lineages. p27-deficient mice that lack both copies of the $p 27$ gene grow approximately one-third larger then normal and contain more cells in all of their organs, apparently as a result of an increase in cell division rather than a decrease in cell death.(44-46) Mice with one inactive copy of the $p 27$ gene are one-sixth larger then normal,(44-46) suggesting that the precise concentration of p27 is important, as would be expected if the accumulation of p27 helps determine when cells stop dividing.

It seems clear, however, that p27 is only a minor component of the timer that operates in precursor cells. p27deficient oligodendrocyte precursor cells, for example, do stop dividing and differentiate in culture in the presence of saturating concentrations of PDGF and TH, just not at precisely the correct time. What, then, are the other components of the timer? The phenotype of mice deficient in another Cdk inhibitor, p18/Ink4c (p18), is very similar to that of p27-deficient mice, suggesting that $p 18$ may be another component.(47) In mice deficient in both p27 and p18, some organs are larger than in mice deficient in either protein alone, but, even in these doubly deficient mice, precursor cells still stop dividing and differentiate during development, suggesting that there are additional components that stop the cell cycle in these mice. ${ }^{(47)}$ It seems likely that some of these other components will turn out to be intracellular cellcycle promoters, such as cyclins or Cdks, whose levels may decrease to help arrest the cell cycle and initiate differentiation. (48)

Genetic studies indicate that p27-like proteins are also present in C. elegans ${ }^{(49)}$ and Drosophila.(49-51) If the genes encoding these proteins are inactivated by mutation, developing cells in multiple lineages go through one or more extra divisions before withdrawing from the cell cycle.(49-51) It seems, therefore, that Cdk inhibitors are involved in stopping the cell cycle at the appropriate time during development of all animals.

\section{The role of thyroid hormone (TH)}

There is abundant evidence that $\mathrm{TH}$ normally plays an important part in timing oligodendrocyte development. Myelination, for example, is delayed in hypothyroid animals ${ }^{(52,53)}$ and accelerated in hyperthyroid animals. ${ }^{(54)}$ Moreover, perinatal hypothyroidism decreases the number of oligodendrocytes that develop in the rat ${ }^{(55)}$ and mouse ${ }^{(56)}$ optic nerve, and $\mathrm{TH}$ increases the number of oligodendrocytes that develop in cultures of brain cells. $(57,58)$ While it is clear that $\mathrm{TH}$ activates the effector component of the timer in oligodendrocyte precursor cells and so stops division and initiates differentiation, it is not clear how this is brought about. It is likely that $\mathrm{TH}$ effects are mediated by the $\beta 1$ isoform of the $\mathrm{TH}$ receptor (TR $\beta 1)$, as TR $\beta 1$ levels increase in cultured precursor cells in parallel with their sensitivity to the triggering effects of $\mathrm{TH}$, whereas levels of $\mathrm{TR} \alpha$ are high from the start, before the cells become sensitive to these effects of TH.(59) Interestingly, TR $\beta 1$ levels increase with the same kinetics as p27, and, like p27, the levels increase faster at $33^{\circ} \mathrm{C}$ then at $37^{\circ} \mathrm{C}$, suggesting that it is also part of the timer in these cells. ${ }^{(59)}$

Because $\mathrm{TH}$ influences the timing of differentiation in various cell lineages, including muscle, neuronal, and erythrocyte lineages, it is likely that it plays a part in coordinating differentiation in different tissues during development. The rodent thyroid gland becomes active around the time of birth, and $\mathrm{TH}$ levels progressively increase during the first weeks of postnatal life. $(52,60,61)$ It is well suited therefore to coordinate events, such as oligodendrocyte differentiation, that occur during this period. It has been shown recently, for instance, that $\mathrm{TH}$ triggers the onset of myelin gene expression in both the Schwann cells and oligodendrocytes that myelinate the peripheral and central branches, respectively, of the VIIIth nerve in neonatal rats, which might help to ensure that nerve conduction rates are high when hearing begins. ${ }^{62}$ Thus, TH may help coordinate some of the events of postnatal mammalian development, just as it orchestrates the events of amphibian metamorphosis. 63,64$)$

\section{An intrinsic maturation program in precursor cells}

Visualisation of oligodendrocyte precursor cells in the rat optic nerve at different developmental times shows that they become progressively more complex as the rats age.(65) Moreover, when these precursor cells are purified at different ages and studied in culture, embryonic precursor cells have a simpler morphology, migrate and divide faster, and divide more times before they differentiate compared to 
postnatal precursor cells. If purified embryonic cells are cultured for 10 days or so, however, so that they become equivalent in age to postnatal cells; the two are indistinguishable. (66) These findings suggest that the precursor cells have an intrinsic maturation program that plays out over time, even when the cells are maintained in a relatively constant environment and in the virtual absence of other cell types. It seems likely, therefore, that the intrinsic timer that controls when these cells stop dividing and differentiate is only one part of a more complex maturation program. It remains a mystery how such an intracellular program is controlled in a way that remains predictable over such a long period of time.

Other types of precursor cells also have an intrinsic maturation program that alters their behaviour and responses to extracellular signals as development proceeds. (67-70) A dramatic example is seen in multipotential progenitor cells isolated from the rodent embryonic cerebral cortex. When cultured on their own in microwells, these cells display stereotyped division patterns, which appear to be cell autonomous and to change with development.(69,71) Similar division patterns are observed during neural development in nematodes ${ }^{(72)}$ and insects, ${ }^{(73)}$ where they reflect the action of both cell-intrinsic developmental programs and cell-cell interactions, which cooperate to generate the diverse cell types that make up the nervous system.

\section{Heterochronic genes}

The identification of some of the components of the timer in oligodendrocyte precursor cells does not indicate how the timer works. One needs to understand how the levels of p27 and TR $\beta 1$ are controlled so they increase with time in the dividing cells in order to do this.

A powerful approach to determine the molecular basis of developmental timers is to identify genes that are involved specifically in regulating the timing of development, these are the so-called heterochronic genes. This approach, for example, has identified heterochronic genes in the nematode, $C$. elegans. ${ }^{(74,75)}$ After hatching from the egg, the worm develops through four larval stages, separated by molts, to become a sexually mature adult. During these larval stages, cell division and differentiation occur at specific times in invariant patterns. (72) Mutations in heterochronic genes cause stage-specific transformations in larval development, such that cells adopt fates that are characteristic of the lineage but from an earlier or later stage of development. ${ }^{(74,75)}$ Studies of these transformations suggest that heterochronic genes normally determine the timing of cell fate choice. ${ }^{(74)}$

Two of these genes Lin-14 and Lin-28 encode intracellular proteins that play a part in cell fate determination. Both proteins decrease progressively during larval development, and this decrease is required for the normal timing of development. The decrease depends on the progressive increase of two small RNAs encoded by a third heterochronic gene Lin-4. The small RNAs bind to the mRNAs encoded by Lin-14 and Lin-28 and inhibit their translation. (76-78) It is unclear, however, what controls the increase in the small RNAs during development. Heterochronic genes have been identified in plants, slime moulds, and fungi, but they have yet to be described in mammals.

\section{Conclusion}

Most of the timing mechanisms that operate during animal development depend on both intracellular timers and cellcell interactions. Although there has been a great deal of progress in understanding the cell-cell interactions that regulate development, much less attention has been paid to the intracellular timers, which therefore remain largely mysterious. Understanding how these timers operate is one of the great challenges for developmental biologists in the future.

\section{References}

1. Coveney P, Highfield R. The arrow of time. London: Flamingo. 1991.

2. Dunlap JC. Molecular bases for circadian clocks. Cell 1999;96:271-290.

3. Pourquie O. Clocks regulating developmental processes. Curr Opin Neurobiol 1998;8:665-670.

4. Dale K, Pourquie O. A clock-work somite. BioEssays 1999;22:71-82.

5. Murray A, Hunt T. The cell cycle. Oxford: Oxford University Press; 1993.

6. Johnson M., Day M. Egg timers. BioEssays 1999;22:56-62.

7. Palmeirim I, Henrique D, Ish-Horowicz D, Pourquie O. Avian hairy gene expression identifies a molecular clock linked to vertebrate segmentation and somitogenesis. Cell 1997;91:639-648.

8. Etkin LD. Regulation of the mid-blastula transition in amphibians. Dev Biol 1985;5:209-225.

9. Newport J, Kirschner M. A major developmental transition in early Xenopus embryos: II. Control of the onset of transcription. Cell 1982;30:687-696.

10. Reddel RR. A reassessment of the telomere hypothesis of senescence. BioEssays 1998;20:977-984.

11. Harris WA, Hartenstein V. Neuronal determination without cell division in Xenopus embryos. Neuron 1991;6:499-515.

12. Satoh N, Araki I, Satou Y. An intrinsic genetic program for autonomous differentiation of muscle cells in the ascidian embryo. Proc Natl Acad Sci USA 1996;93:9315-9321.

13. McGrew MJ, Dale JK, Fraboulet S, Pourquie $O$. The lunatic fringe gene is a target of the molecular clock linked to somite segmentation in avian embryos. Curr Biol 1998;8:979-982.

14. Newport J, Dasso M. On the coupling between DNA replication and mitosis. J Cell Sci Suppl 1989;12:149-160.

15. Abney ER, Bartlett PP, Raff MC. Astrocytes, ependymal cells, and oligodendrocytes develop on schedule in dissociated cell cultures of embryonic rat brain. Dev Biol 1981;83:301-310.

16. Small RK, Riddle P, Noble M. Evidence for migration of oligodendrocytetype-2 astrocyte progenitor cells into the developing rat optic nerve. Nature (London) 1987;328:155-157.

17. Miller RH, David S, Patel R, Abney ER, Raff MC. A quantitative immunohistochemical study of macroglial cell development in the rat optic nerve: In vivo evidence for two distinct astrocyte lineages. Dev Biol 1985;111:35-41.

18. Barres B, Hart I, Coles H, Burne J, Voyvodic J, Richardson W, Raff M. Cell death and control of cell survival in the oligodendrocyte lineage. Cell 1992; 70:31-46.

19. Richardson WD, Pringle N, Mosley MJ, Westermark B, Dubois-Dalcq M. A role for platelet-derived growth factor in normal gliogenesis in the central nervous system. Cell 1988;53:309-319. 
20. Noble M, Murray K. Purified astrocytes promote the in vitro division of a bipotential glial progenitor cell. EMBO J 1984;3:2243-2247.

21. Fruttiger M, Karlsson L, Hall AC, Abramsson A, Calver AR, Bostrom H, Willetts K, Bertold CH, Heath JK, Betsholtz C, Richardson WD. Defective oligodendrocyte development and severe hypomyelination in PDGF-A knockout mice. Development 1999;126:457-467.

22. Calver AR, Hall AC, Yu WP, Walsh FS, Heath JK, Betsholtz C, Richardson WD. Oligodendrocyte population dynamics and the role of PDGF in vivo. Neuron 1998:20:869-882

23. Fruttiger M, Calver AR, Kruger WH, Mudhar HS, Michalovich D, Takakura N, Nishikawa S, Richardson WD. PDGF mediates a neuron-astrocyte interaction in the developing retina. Neuron 1996;17:1117-1131.

24. Raff M, Abney E, Fok-Seang J. Reconstitution of a developmental clock in vitro: A critical role for astrocytes in the timing of oligodendrocyte differentiation. Cell 1985;42:61-69.

25. Raff M, Lillien L, Richardson W, Burnem J, Noble M. Platelet-derived growth factor from astrocytes drives the clock that times oligodendrocyte development in culture. Nature 1988:333:562-565.

26. Hart IK, Richardson WD, Heldin CH, Westermark B, Raff MC. PDGF receptors on cells of the oligodendrocyte-type-2 astrocyte $(\mathrm{O}-2 \mathrm{~A})$ cell lineage. Development 1989;105:595-603.

27. Hart IK, Richardson WD, Bolsover SR, Raff MC. PDGF and intracellular signalling in the timing of oligodendrocyte differentiation. J Cell Biol 1989;109: 3411-3417.

28. Hart I, Richardson W, Raff M. PDGF increases the expression of fos and jun in newly formed oligodendrocytes that have become resistant to the mitogenic effect of PDGF. Glia 1992;6:310-313.

29. Temple S, Raff M. Clonal analysis of oligodendrocyte development in culture: Evidence for a developmental clock that counts cell divisions. Cell 1986;44: 773-779.

30. Barres B, Lazar M, Raff M. A novel role for thyroid hormone, glucocorticoids and retinoic acid in timing oligodendrocyte development. Development 1994; 120:1097-1108.

31. Gao FB, Durand B, Raff M. Oligodendrocyte precursor cells count time but not cell divisions before differentiation. Curr Biol 1997;7:152-155.

32. Raff MC, Miller RH, Noble M. A glial progenitor cell that develops in vitro into an astrocyte or an oligodendrocyte depending on culture medium. Nature 1983;303:390-396.

33. Barres B, Raff M. Control of oligodendrocyte number in the developing rat optic nerve. Neuron 1994;12:935-942.

34. Bögler $\mathrm{O}$, Noble M. Measurement of time in oligodendrocyte-type 2 astrocyte $(\mathrm{O}-2 \mathrm{~A})$ progenitors is a cellular process distinct from differentiation or division. Dev Biol 1994;162:525-538.

35. Grove EA, Williams BP, Li DG, Hajihosseini M, Friedrich A, Price J. Multiple restricted lineages in the embryonic rat cerebral cortex. Development 1993; 117:553-561.

36. Morgan D. Principles of CDK regulation. Nature 1995;374:131-134

37. Lees E. Cyclin dependent kinase regulation. Curr Opin Cell Biol 1995;7:773780 .

38. Sherr C. G 1 phase progression: Cycling on cue. Cell 1994;79:551-556.

39. Sherr CJ, Roberts JM. Inhibitors of mammalian $G_{1}$ cyclin-dependent kinases. Genes Dev 1995:9:1149-1163.

40. Nakayama K, Nakayama K. Cip/Kip cyclin-dependent kinase inhibitors: Brakes of the cell cycle engine during development. BioEssays 1998;20: 1020-1029.

41. Durand B, Gao FB, Raff M. Accumulation of the cyclin-dependent kinase inhibitor p27/Kip1 and the timing of oligodendrocyte differentiation. EMBO J 1997;16:306-317.

42. Durand B, Fero ML, Roberts JM, Raff MC. p27Kip1 alters the response of cells to mitogen and is part of a cell-intrinsic timer that arrests the cell cycle and initiates differentiation. Curr Biol 1998;8:431-440.

43. Casaccia-Bonnefil P, Tikoo R, Kiyokawa H, Friedrich V Jr, Chao MV, Koff A. Oligodendrocyte precursor differentiation is perturbed in the absence of the cyclin-dependent kinase inhibitor p27Kip1. Genes Dev 1997;11:2335-2346.

44. Fero M, Rivkin M, Tasch M, Porter P, Carow C, Firpo E, Polyak K, Tsai L-H, Broudy V, Perlmutter R, Kaushansky K, Roberts J. A syndrome of multi-organ hyperplasia with features of gigantism, tumorigenesis and female sterility in p27Kip1-deficient mice. Cell 1996;85:733-744.

45. Nakayama K, Ishida N, Shirane M, Inomata A, Inoue T, Shishido N, Horii I, Loy D, and Nakayama K-I. Mice lacking p27Kip1 display increased body size, multiple organ hyperplasia, retinal dysplasia and pituitary tumors. Cell 1996 85:707-720

46. Kiyokawa H, Kineman R, Manova-Todorova K, Soares V, Hollman E, Ono M, Khanam D, Hayday A, Frohman L, Koff A. Enhanced growth of mice lacking the cyclin-dependent kinase inhibitor function of p27Kip1. Cell 1996;85:721732.

47. Franklin DS, Godfrey VL, Lee H, Kovalev GI, Schoonhoven R, Chen-Kiang S, Su L, Xiong Y. CDK inhibitors p18(INK4c) and p27(Kip1) mediate two separate pathways to collaboratively suppress pituitary tumorigenesis. Genes Dev 1998;12;2899-2911.

48. Knoblich J, Sauer K, Jones L, Richardson H, Saint R, Lehner C. Cyclin E controls $S$ phase progression and its down regulation during Drosophila embryogenesis is required for the arrest of cell proliferation. Cell 1994;77: 107-120.

49. Hong $Y$, Roy R, Ambros V. Developmental regulation of a cyclin-dependent kinase inhibitor controls postembryonic cell cycle progression in Caenorhabditis elegans. Development 1998;125:3585-3597.

50. de Nooij J, Letendre M, Hariharan I. A cyclin-dependent kinase inhibitor, Dacapo, is necessary for timely exit from the cell cycle during drosophila embryogenesis. Cell 1996;87:1237-1247.

51. Lane M, Sauer K, Wallace K, Jan Y-N, Lehner C, Vaessin H. Dacapo, a cyclin-dependent kinase inhibitor stops cell proliferation during drosophila development. Cell 1996;87:1225-1235.

52. Dussault JH, Ruel J. Thyroid hormones and brain development. Annu Rev Physiol 1987;49:321-334.

53. Rodriguez-Pena A, Ibarrola N., Iniguez MA, Munoz A, Bernal J. Neonatal hypothyroidism affects the timely expression of myelin-associated glycoprotein in the rat brain. J Clin Invest 1993;91:812-818.

54. Walters SN, Morell P. Effects of altered thyroid states on myelinogenesis. J Neurochem 1981;36:1792-1801.

55. Ibarrola N, Mayer-Proschel M, Rodriguez-Pena A, Noble M. Evidence for the existence of at least two timing mechanisms that contribute to oligodendrocyte generation in vitro. Dev Biol 1996;180:1-21.

56. Ahlgren SC, Wallace H, Bishop J, Neophytou C, Raff MC. Effects of thyroid hormone on embryonic oligodendrocyte precursor cell development in vivo and in vitro. Mol Cell Neurosci 1997;9:420-432.

57. Almazan G, Honegger P, Matthieu JM. Triiodothyronine stimulation of oligodendroglial differentiation and myelination. A developmental study. Dev Neurosci 1985;7:45-54.

58. Koper JW, Hoeben RC, Hochstenbach FM, van Golde LM, Lopes-Cardozo M. Effects of triiodothyronine on the synthesis of sulfolipids by oligodendrocyte-enriched glial cultures. Biochim Biophys Acta 1986;887:327-334.

59. Gao FB, Apperly J, Raff M. Cell-intrinsic timers and thyroid hormone regulate the probability of cell-cycle withdrawal and differentiation of oligodendrocyte precursor cells. Dev Biol 1998;197:54-66.

60. Puymirat J. Thyroid receptors in the rat brain. Prog Neurobiol 1992;39:281294.

61. Samel M. Thyroid function during postnatal development in the rat. Gen Comp Endocrinol 1968;10:229-234.

62. Knipper M, Bandtlow C, Gestwa L, Kopschall I, Rohbock K, Wiechers B, Zenner HP, Zimmermann U. Thyroid hormone affects Schwann cell and oligodendrocyte gene expression at the glial transition zone of the VIIIth nerve prior to cochlea function. Development 1998;125:3709-3718.

63. Shi YB, Wong J, Puzianowska-Kuznicka M, Stolow MA. Tadpole competence and tissue-specific temporal regulation of amphibian metamorphosis: Roles of thyroid hormone and its receptors. BioEssays 1996;18:391399.

64. Wang Z, Brown DD. Thyroid hormone-induced gene expression program for amphibian tail resorption. J Biol Chem 1993;268:16270-16278.

65. Fulton BP, Burne JF, Raff MC. Visualization of O-2A progenitor cells in developing and adult rat optic nerve by quisqualate-stimulated cobalt uptake. J Neurosci 1992;12:4816-4833.

66. Gao FB, Raff M. Cell size control and a cell-intrinsic maturation program in proliferating oligodendrocyte precursor cells. J Cell Biol 1997;138:13671377.

67. Cooke J, Smith JC. Measurement of developmental time by cells of early embryos. Cell 1990;60:891-894.

68. Lillien L. Progenitor cells: What do they know and when do they know it? Curr Biol 1998:8:872-874.

\section{BioEssays 22.1}


69. Shen Q, Qian X, Capela A, Temple S. Stem cells in the embryonic cerebral cortex: Their role in histogenesis and patterning. J Neurobiol 1998;36:162174.

70. Belliveau MJ, Cepko CL. Extrinsic and intrinsic factors control the genesis of amacrine and cone cells in the rat retina. Development 1999;126:555566.

71. Qian X, Goderie SK, Shen Q, Stern JH, Temple S. Intrinsic programs of patterned cell lineages in isolated vertebrate CNS ventricular zone cells. Development 1998;125:3143-3152

72. Sulston JE, Horvitz HR. Post-embryonic cell lineages of the nematode, Caenorhabditis elegans. Dev Biol 1977;56:110-156.

73. Doe CQ, Skeath JB. Neurogenesis in the insect central nervous system. Curr Opin Neurobiol 1996;6:18-24.
74. Ambros V, Moss EG. Heterochronic genes and the temporal control of $C$. elegans development. Trends Genet 1994;10:123-127.

75. Slack F, Ruvkun G. Temporal pattern formation by heterochronic genes Annu Rev Genet 1997;31:611-634.

76. Moss EG, Lee RC, Ambros V. The cold shock domain protein LIN-28 controls developmental timing in C. elegans and is regulated by the lin-4 RNA. Cell 1997:88:637-646.

77. Hal, Wightman B, Ruvkun G. A bulged lin-4/lin-14 RNA duplex is sufficient for Caenorhabditis elegans lin-14 temporal gradient formation. Genes Dev 1996; 10:3041-3050

78. Wightman B, Ha I, Ruvkun G. Posttranscriptional regulation of the heterochronic gene lin-14 by lin-4 mediates temporal pattern formation in C. elegans. Cell 1993;75:855-862. 